\title{
Prevalence of Anguillicoloides crassus and growth variation in migrant yellow-phase American eels of the upper Potomac River drainage
}

\author{
Jennifer L. Zimmerman ${ }^{1}$, Stuart A. Welsh' ${ }^{2, *}$ \\ ${ }^{1}$ Division of Forestry and Natural Resources, West Virginia University, Morgantown, West Virginia 26506, USA \\ ${ }^{2}$ US Geological Survey, West Virginia Cooperative Fish and Wildlife Research Unit, West Virginia University, Morgantown, \\ West Virginia 26506, USA
}

\begin{abstract}
Prevalence of the non-native swim bladder nematode Anguillicoloides crassus has recently increased in American eels from estuaries of the North American Atlantic coast, but little is known about parasite prevalence or conditions of previous infection in upstream migrant eels within upper watersheds. This study is the first to confirm presence of $A$. crassus in the upper Potomac River watershed. We estimated A. crassus prevalence during 3 time periods: September to October 2006 (5/143 eels, 3.5\%), August to October 2007 (0/49 eels), and June 2008 (0/50 eels). All eels were sampled from the Millville Dam eel ladder on the lower Shenandoah River, a Potomac River tributary located approximately $285 \mathrm{~km}$ upstream of Chesapeake Bay, USA. Of the 5 infected eels, parasite intensity was 1 for each eel, and mean intensity was also 1.0. A swim bladder degenerative index (SDI) was calculated for the 50 eels from the final sampling period, and $38 \%$ of those eels (19 of 50) showed signs of previous infection by A. crassus. We also aged 42 of the 50 eels (mean $\pm \mathrm{SE}=6.7 \pm 0.29 \mathrm{yr}$, range 4 to $11 \mathrm{yr}$ ) from the final sampling period. Based on the range of possible SDI scores (0 to 6), severity of previously infected swim bladders was moderate (SDI = 1 or 2). Previously infected eels, however, had a lower length-at-age than that of uninfected eels. Female yellow-phase eels in upper watersheds develop into large highly fecund silver-phase adults; hence, a parasite-induced effect on growth of yellow-phase eels could ultimately reduce reproductive potential.
\end{abstract}

KEY WORDS: Anguilla rostrata $\cdot$ Growth $\cdot$ Swim bladder degenerative index $\cdot$ Shenandoah River

\section{INTRODUCTION}

The American eel Anguilla rostrata, a commercially important species along the Atlantic coast of North America, has declined in population size since the 1980s (Haro et al. 2000, Richkus \& Whalen 2000, Casselman 2003). Direct causes of the population decline are difficult to determine, owing partly to the American eel's wide geographic distribution and its complex catadromous life history, which includes larval, glass, elver, yellow, and silver phases. Many yellow-phase eels migrate long distances toward river headwaters, and adult silver-phase eels migrate long distances from rivers to the Sargasso Sea. Along these migration routes, habitat modification, fishing pressure, pollution, and oceanic changes are possible contributors to American eel population decline (Castonguay et al. 1994a,b, Haro et al. 2000).

The non-native swim bladder nematode parasite Anguillicoloides crassus may also contribute to American eel population decline (Haro et al. 2000). Researchers have suggested that $A$. crassus-infected adult silver eels may be unable to complete downstream and oceanic spawning migration to the Sargasso Sea (Kirk et al. 2000). Further, A. crassus infections may degrade swim bladders, and thus impact 
swimming performance of infected and post-infected eels (Sprengel \& Lüchtenberg 1991, Palstra et al. 2007). It is also possible that upstream migration may be compromised in A. crassus-infected or postinfected yellow-phase eels, which could contribute to population decline by ultimately reducing numbers of large fecund eels in headwater areas.

Anguillicoloides crassus is possibly native to Asia, where it occurs in the Japanese eel Anguilla japonica (Nagasawa et al. 1994). The scientific name of this nematode, previously Anguillicola crassus, was revised by Moravec (2006). Its life cycle, which is completed in less than 2 mo under laboratory conditions, includes intermediate and paratenic hosts (De Charleroy et al. 1990). Juvenile and adult eels can become infected by eating infected intermediate or paratenic hosts (De Charleroy et al. 1990). During the 1980s, A. crassus was introduced to Europe (Peters \& Hartman 1986, Kennedy \& Fitch 1990, Kangur et al. 2010) and has been implicated in population decline of European eel Anguilla anguilla (Palstra et al. 2007). During the 1990s, A. crassus was observed in swim bladders of American eel in North America, and has since been documented along the Atlantic coast of the United States, as well as New Brunswick and Nova Scotia, Canada (Barse \& Secor 1999, Barse et al. 2001, Moser et al. 2001, Geer 2003, Morrison \& Secor 2003, Sokolowski \& Dove 2006, Machut \& Limburg 2008, Aieta \& Oliveira 2009, Rockwell et al. 2009, Fenske et al. 2010).

Research on Anguillicoloides crassus infection of eels has often focused on prevalence, intensity, and mean intensity to determine parasite infection rates (Lefebvre et al. 2002, Sokolowski \& Dove 2006). Studies on European eel, however, have shown that these values may underestimate impacts of $A$. crassus on eels (van Banning \& Haenen 1990, Molnár et al. 1994, Lefebvre et al. 2002). Further, buoyancy control, oxygen exchange, and acid-base homeostasis functions of infected and previously infected swim bladders may be compromised, causing physiological and behavioral changes in eels (Molnár et al. 1993, Würtz et al. 1996, Würtz \& Taraschewski 2000, Lefebvre et al. 2002, Tesch 2003).

Pathological changes to the swim bladder may be a better indicator of a parasite's effect than just the number of worms alone (Lefebvre et al. 2002). A swim bladder degenerative index (SDI), developed by Lefebvre et al. (2002), quantifies swim bladder health based on 3 criteria; the transparency or opacity of the swim bladder wall, presence of pigmentation and exudates, and thickness of the swim bladder wall. This macroscopic measure of swim bladder health allows for easy quantification of present and previous infections (Lefebvre et al. 2002).

In this study, one objective was to estimate rates of Anguillicoloides crassus infection and previous infection of eels from the lower Shenandoah River, a Potomac River tributary located approximately $285 \mathrm{~km}$ upstream of Chesapeake Bay, USA. Several studies of A. crassus-infected American eels have documented prevalence in rivers near coastal areas of the Atlantic coast, but less is known about parasite prevalence or conditions of previous infection in yellow-phase eels within upper watersheds. A second objective was to examine age-length relationships between upstream migrant eels with and without signs of previously infected swim bladders.

\section{MATERIALS AND METHODS}

A total of 242 yellow-phase American eels were collected from an eel ladder on Millville Dam of the lower Shenandoah River, a large tributary within the Potomac River drainage of Chesapeake Bay. The Millville Dam eel ladder, a stainless steel structure with a length of $11 \mathrm{~m}$ and a slope of $50^{\circ}$, has been described by Hildebrand (2005). Millville Dam is a low head (5 $\mathrm{m}$ height) hydroelectric dam located approximately $9 \mathrm{~km}$ upstream of Harpers Ferry, West Virginia, at the confluence of Shenandoah River with Potomac River, $100 \mathrm{~km}$ upstream of the Potomac River at head of tide, and $285 \mathrm{~km}$ upstream from the mouth of the Potomac River estuary (Fig. 1).

American eels were collected during 3 time periods: September to October 2006 ( $n=143)$, August to October 2007 ( $\mathrm{n}=49$ ), and June 2008 ( $\mathrm{n}=50)$. After collection, eels were killed with an overdose of clove oil (Eugenol), frozen, and transported to the laboratory for swim bladder evaluation. For each eel, we measured total length (mm), and used a dissecting microscope to examine swim bladders for presence of pre-adult and adult parasites. Parasite identification followed descriptions of Moravec \& Taraschewski (1988). The number of parasites in each eel was recorded, and prevalence, intensity, mean intensity, and associated $95 \%$ confidence intervals were calculated (Bush et al. 1997). Prevalence was estimated as the number of eels infected with Anguillicoloides crassus divided by the total number of eels in the sample. Intensity was calculated as the total number of $A$. crassus nematodes for each infected eel. Mean intensity was estimated as the total number of $A$. crassus individuals found within infected eels divided by the total number of eels infected by the parasite. 


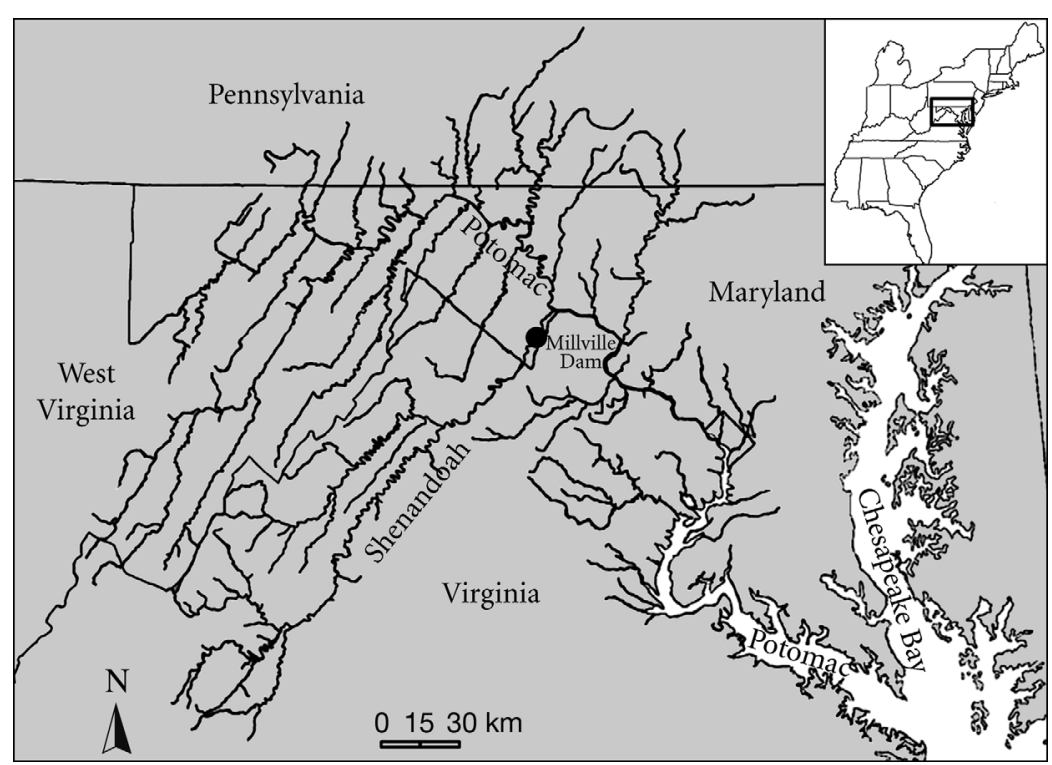

Fig. 1. American eel sampling site located at Millville Dam approximately $285 \mathrm{~km}$ upstream of the mouth of the Potomac River of Chesapeake Bay, USA

all 50 eels from this sample because some otoliths were damaged during preparation, but a total of 42 eels were aged successfully following methods of Oliveira (1996). Sagittal otoliths were extracted and then embedded in epoxy resin. Embedded otoliths were cut transversely with a diamond wafering saw (Buehler Isomet 1000). Once cut, the sections were first placed on a slide with thermoplastic crystalbond glue, and then ground and polished. Otolith sections were etched and stained using $2 \%$ EDTA and 5\% toluidine blue. Ages were estimated by counting the number of annual rings along multiple axes. An additional year was added to the age estimate to account for the larval salt water phase.

We used ANCOVA to examine differences in slopes and intercepts of age-length relationships between eels

Parasite-induced macroscopic damage to swim bladders of the 50 eels from the final sampling period of June 2008 was assessed using the SDI. We were unaware of the SDI method during the first 2 sampling periods. The SDI scores were recorded based on the following 3 criteria of Lefebvre et al. (2002): (1) Opacity of the swim bladder wall, (2) presence of pigmentation and exudates, including dead worms, erythrocytes, decaying swim bladder tissue, eggs, and $\mathrm{L}_{2}$ Anguillicoloides crassus, and (3) thickness of the swim bladder wall. Scores of 0 to 2 were assigned to each criterion with increasing swim bladder degradation. For the transparency of the swim bladder, a score of 0 indicated a normal transparent swim bladder, a 1 indicated intermediate opacity, and a 2 meant that the swim bladder was completely opaque. For the second category, a score of 0 indicated an absence of exudate and pigment. If either exudate or pigment were found, a score of 1 was assigned, and a 2 was given when both exudates and pigments were present. Swim bladder wall thickness, measured with stacked $1 \mathrm{~mm}$ glass slides (Molnár et al. 1994), was scored as 0 for $<1.0 \mathrm{~mm}, 1$ for 1.0 to $3.0 \mathrm{~mm}$, and 2 for $>3.0 \mathrm{~mm}$. The cumulative index score (i.e. the SDI) ranged from 0 to 6 , with a value of 0 corresponding to a healthy swim bladder, 1 to 3 being a moderately damaged swim bladder, and 4 to 6 being a severely damaged swim bladder.

We were interested in the relationship between eel age and SDI, so we estimated ages of eels from the final sampling period. We were unsuccessful at aging with healthy $(\mathrm{SDI}=0)$ and degraded $(\mathrm{SDI}>0)$ swim bladder conditions. As age-length relationships reflect fish growth, ANCOVA assessed the relationship between swim bladder condition and eel growth. For this analysis, non-rejection of the null hypothesis of equal slopes provides evidence that growth rates are similar between eels of the 2 SDI groups. Additionally, we tested the null hypothesis of equal intercepts between the 2 SDI groups. Given equal slopes, a significant difference between intercepts provides evidence for a growth effect by demonstrating that length-atage differs between eels of the 2 SDI groups. For ANCOVA, lengths and ages of eels were $\log _{\mathrm{e}}$-transformed to meet assumptions of normality. Statistical significance was assessed at $\mathrm{p} \leq 0.05$.

\section{RESULTS}

Prevalence of the parasite was $2.1 \%$ (5/242 eels, CI $=1.4$ to 6.8 ) for pooled data of the 3 sampling periods. Total lengths $(T L)$ for all eels $(n=242)$ ranged from 200 to $527 \mathrm{~mm}$ (mean $\pm \mathrm{SE}=351.5 \pm 3.8 \mathrm{~mm}$ ). When sampling periods were analyzed separately, prevalence was $3.5 \%$ (5/143 eels, CI $=2.4$ to 11.5$)$ for September to October 2006. However, swim bladder nematodes were not found in the 49 and 50 eels collected during August to October 2007 and June 2008, respectively. Of the 5 infected eels found during 2006, intensity was 1 for each eel. Mean intensity was also 1.0 (5 adult nematodes/5 eels). 
Based on the SDI, 19 of 50 eels $(38 \%, C I=24.7$ to $52.8 \%$ ) showed signs of previous infection (i.e. SDI > 0) by Anguillicoloides crassus; 10 and 9 eels had an SDI score of 1 or 2, respectively. Of these 50 eels, 31 ( $62 \%, \mathrm{CI}=47.2$ to $75.3 \%$ ) had healthy swim bladders $(\mathrm{SDI}=0)$. None of the 50 eels had severely degraded swim bladders. The SDI scores were influenced by the first and second scoring criteria. For the first SDI criterion, the swim bladder wall displayed normal transparency (score $=0$ ) for 42 individuals and intermediate opacity (score $=1$ ) for 8 individuals. For the second criterion, 33 individuals displayed no pigmentation or exudates (score $=0$ ), 14 included either pigment or exudates (score $=1$ ), and 3 had both pigment and exudates associated with the swim bladder $($ score $=2)$. For the final criterion, all 50 individuals had normal thickness of swim bladder walls $(<1 \mathrm{~mm}$ thickness, score $=0$ ).

Lengths and ages were compared between uninfected and previously infected eels from the June 2008 sampling period. A total of 42 eels were aged from the June 2008 sample of 50 eels (mean $6.7 \pm$ $0.29 \mathrm{yr}$, range 4 to $11 \mathrm{yr}$ ). Of these 42 eels, 15 eels had signs of previously infected swim bladders (SDI $>0$, mean length $326.6 \pm 13.3 \mathrm{~mm} \mathrm{TL}$, length range 255 to $421 \mathrm{~mm} \mathrm{TL}$; mean age $6.9 \pm 0.55 \mathrm{yr}$, age range 4 to $11 \mathrm{yr}$ ) and 27 had healthy swim bladders (SDI $=0$; mean length $346.5 \pm 11.4 \mathrm{~mm} \mathrm{TL}$, length range 244 to $467 \mathrm{~mm} \mathrm{TL}$; mean age $6.6 \pm 0.33 \mathrm{yr}$, age range 4 to $10 \mathrm{yr})$.

Based on ANCOVA, slopes of age-length relationships were not significantly different between eels with healthy and moderately degraded swim bladders $(p=0.44)$. Similar slopes of age-length relationships provided evidence that growth rates of eels were similar between uninfected eels and those showing signs of previous infection (Fig. 2). The intercept for eels with healthy swim bladders, however, was $24.4 \mathrm{~mm}$ higher and significantly greater $(p=0.03)$ than that of eels with moderately degraded swim bladders (Fig. 2). Given equal age-length regression slopes, the significant difference between intercepts supports a higher length-at-age in eels with healthy swim bladders than that of eels with moderately degraded swim bladders.

\section{DISCUSSION}

This study provides the first documented record of Anguillicoloides crassus from the lower Shenandoah River, an upper Potomac River tributary. It provides 3 findings associated with $A$. crassus infection relevant

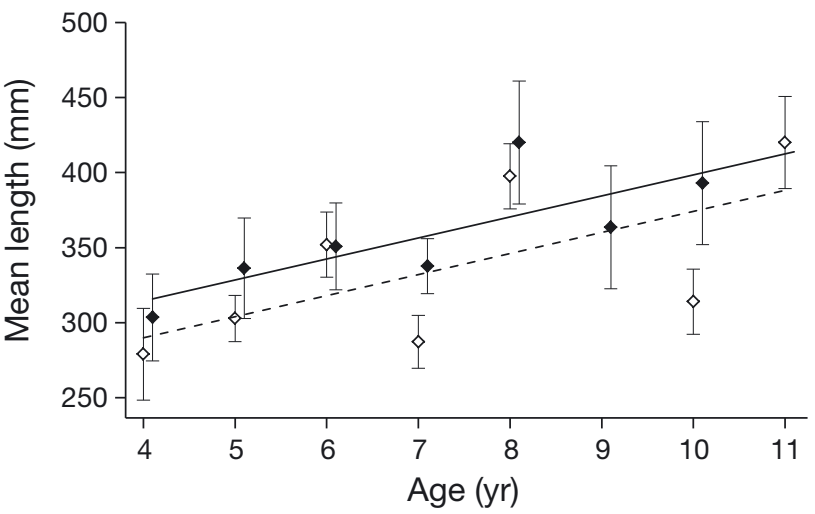

Fig. 2. Anguilla rostrata infected with Anguillicoloides crassus. Mean $( \pm \mathrm{SE})$ length-at-age of uninfected $(\bullet$, solid leastsquares regression line, $\mathrm{n}=27)$ and previously infected $(\diamond$, dashed least-squares regression line, $\mathrm{n}=15$ ) upstream migrant yellow-phase American eels collected at Millville Dam, Shenandoah River, USA

to the conservation and management of American eels. First, our study found a low prevalence rate ( 5 of 242 eels, $2.1 \%$ ) of A. crassus in American eels of the lower Shenandoah River, a distance of approximately $285 \mathrm{~km}$ upstream of Chesapeake Bay. Second, although prevalence was low, the rate of previous infection was $38 \%$, and swim bladder conditions were scored as moderately degraded based on a swim bladder degenerative index (SDI). Finally, data supported a greater length-at-age in eels with healthy swim bladders than that of eels with moderately degraded swim bladders.

The $2.1 \%$ prevalence rate of Anguillicoloides crassus in our study is less than that reported from estuarine sections of other tributaries of the Chesapeake Bay (Barse \& Secor 1999, Barse et al. 2001, Geer 2003, Fenske et al. 2010) and from sites north and south of Chesapeake Bay (Moser et al. 2001, Aieta \& Oliveira 2009). American eels from St. Jeromes Creek near the mouth of the Potomac River of Chesapeake Bay had prevalence rates of $40.0 \%$ for adult parasites and $57.1 \%$ for juveniles (Barse et al. 2001). Fenske et al. (2010) found a range of parasite prevalence from 17.8 to $72 \%$ for American eels in estuarine sections of the Chester, Choptank, James, Patuxent, Potomac, and Sassafras rivers of Chesapeake Bay. American eels in the James, Rappahannock, and York rivers of Chesapeake Bay had prevalence rates of 21, 44, and $61 \%$, respectively (Geer 2003). Parasite prevalence ranged from 26 to $100 \%$ in rivers and coastal areas of North Carolina (Moser et al. 2001), 7 to $76 \%$ in Massachusetts, Rhode Island, and Maine (Aieta \& Oliveira 2009), and 3 to $30 \%$ in New Brunswick and Nova Scotia (Aieta \& Oliveira 2009, Rockwell et al. 2009). 
Rapid dissemination of the parasite has been documented within watersheds (Kennedy \& Fitch 1990, Kirk 2003, Morrison \& Secor 2003, Kennedy 2007). However, it is unclear as to how parasite prevalence differs temporally among eels in lower (near coast) and upper river sections. Barse et al. (2001) reported that in some Chesapeake Bay sites, prevalence doubled during the $2 \mathrm{yr}$ duration of their study. Morrison \& Secor (2003) also reported an increase in parasite prevalence during a 1997 to 2000 Hudson River study. Parasite prevalence did not increase during our $3 \mathrm{yr}$ study. Large sample sizes, however, may be required to document the presence of the parasite when prevalence is low. During 2006, we found 5 individuals of Anguillicoloides crassus in a sample size of 143 eels, but did not find the parasite in sample sizes of 49 and 50 eels during 2007 and 2008, respectively.

The range of prevalence rates of 17.8 to $72 \%$ in sub-estuaries of Chesapeake Bay, as cited above, exceeds our $285 \mathrm{~km}$ upstream estimate of $2.1 \%$, but brackets our $38 \%$ rate of previous infection. Possibly, differences in prevalence between estuaries and upstream sites result from the parasite's completion of the estimated 2 mo life cycle without possibility of eel reinfection at upstream sites. We do not know if $A n-$ guillicoloides crassus within eels in the Shenandoah River represent infected eels that migrate upstream from Chesapeake Bay, or if eels become infected after upstream migration. It seems likely that the latter scenario, which would require the presence of paratenic or intermediate hosts in upstream areas, would result in a higher prevalence of A. crassus within eels in the Shenandoah River. Machut \& Limburg (2008) found that physical barriers likely reduced A. crassus infection in the Hudson River, New York. Specifically, small paratenic or intermediate host species may be unable to circumvent dams, thus upstream migrant eels are primarily responsible for the invasion of the parasite (Machut \& Limburg 2008). Machut \& Limburg (2008) also found that eels from tributaries of the tidal Hudson River, New York, had lower parasite prevalence than those at sites lower in the watershed and nearer to coastal areas.

Although the short life-cycle duration of the parasite and a lack of paratenic or intermediate host species may explain low prevalence rates in eels within upper watersheds, several alternative explanations are also possible for the lower prevalence of the parasite in our Shenandoah River study compared to that of Chesapeake Bay studies. Infected eels with high parasite intensity may either not migrate or have reduced upstream migration rates, or suffer high mortality rates in downstream areas. Of the 5 infected eels from the lower Shenandoah River, each had a single nematode worm. Based on the results of the swim bladder degenerative index, the $38 \%$ of eels that exhibited conditions of previous infection only had moderate damage to their swim bladder and none of the eels had severe damage. It is possible that eels in this watershed are not severely infected, or those with severe infection or severe swim bladder damage died further downstream. Mass mortalities caused by the infection in conjunction with other environmental factors have been reported in other species of both farmed and wild anguillid eels (Molnár et al. 1991, 1994, Nagasawa et al. 1994). Additionally, infected eels are intolerant to high temperatures and hypoxia (Molnár 1993, Gollock et al. 2005a,b, Lefebvre et al. 2007); conditions that frequently occur in the Chesapeake Bay (Kemp et al. 1992, Hagy et al. 2004). Infected eels may also be more susceptible to harvest or predation (Gollock et al. 2004, Kennedy 2007, Fazio et al. 2009). The low prevalence estimates and lack of eels with severely degraded swim bladders could also be influenced by our sampling gear, an eel ladder that slopes $50^{\circ}$ and extends $11 \mathrm{~m}$ on Millville Dam. Infected or previously infected eels with compromised swimming ability may be unable to ascend the ladder, which would exclude those eels from our sample.

We do not know if the estimated $38 \%$ of eels which showed signs of previous infection initially had low or high parasite intensities. Further, some previously infected eels may not display a degraded swim bladder condition, because pathological changes may require multiple infection events (van Banning \& Haenen 1990, Molnár et al. 1994, Würtz \& Tarachewski 2000). In a laboratory study, Würtz \& Tarachewski (2000) found that eels infected with up to 40 larvae showed no serious alterations of the swim bladder, and that infections of up to 20 larvae for a period of $20 \mathrm{wk}$ did not cause a thickening of the swim bladder wall. Thus, the percent of previously infected eels from our sample could be higher than $38 \%$.

In our study, length-at-age in eels with healthy swim bladders was consistently higher than that of eels with moderately degraded swim bladders, but growth rates were similar between the 2 groups. Possibly, growth reduction occurred when eels were infected, which could explain why previously infected eels have a lower mean length-at-age than uninfected eels. Behavioral or physiological changes affecting foraging of infected eels may explain growth differences between previously infected and uninfected migrant eels from the lower Shenandoah River. Parasite-induced influences on feeding have occurred in farmed eels; loss of appetite and emaciation have 
been reported for infected eels from aquaculture facilities (van Banning \& Haenen 1990, Nagasawa et al. 1994). If swimming ability is reduced in infected eels (Sprengel \& Lüchtenberg 1991, Palstra et al. 2007), then foraging behavior may also be affected, which could influence growth. Fazio et al. (2009) used hemoglobin $\alpha$-chain $(\mathrm{Hb} \alpha)$ gene expression to examine the effect of Anguillicoloides crassus on physiological mechanisms regulating hematopoiesis in European eels. From that study, Fazio et al. (2009) concluded that infected eels may suffer a reduced aerobic capacity leading to reduced feeding.

Other studies, however, have not found relationships between eel growth and parasite prevalence or previous infections. Fenske et al. (2010) did not find growth differences between infected and uninfected eels or between previously infected and uninfected eels in sub-estuaries of Chesapeake Bay. Also, several studies have demonstrated that eel condition factors (based on length-weight relationships) do not differ between infected and uninfected eels (Han et al. 2008, Fazio et al. 2009, Fenske et al. 2010). These studies, however, did not include upstream migrants, such as those examined in our study. Upstream migrants must trade off energetic costs of foraging and migration, which could have negative consequences on growth, particularly if normal foraging and migration behaviors are altered in infected eels.

Our observational field study lacks experimental controls, and thus, includes uncertainty of cause and effect. We do not know if growth differences between previously infected and uninfected eels were parasite-induced or associated with an unmeasured variable. Barber (2005) reported that parasites grow larger in faster growing fish hosts. Possibly, faster growing parasitized eels are culled from the population of upstream migrants through parasite-induced mortality, altered migratory behavior, or increased vulnerability to predation (Barse \& Secor 1999) or harvest (Sprengel \& Lüchtenberg 1991).

In conclusion, migrant yellow-phase American eels from the lower Shenandoah River of the Potomac River watershed, a site $285 \mathrm{~km}$ upstream of Chesapeake Bay, had relatively low parasite prevalence $(2.1 \%)$ compared to other Chesapeake Bay studies, but $38 \%$ showed signs of previous swim bladder infection. In addition to the low prevalence rate, an interesting finding was a lower length-at-age of previously infected eels than that of uninfected eels. Female yellow-phase eels in upper watersheds develop into large highly fecund silver-phase adults; hence, a parasiteinduced effect on growth of yellow-phase eels could ultimately reduce reproductive potential.
Acknowledgements. Funding was provided by Allegheny Energy Supply and the West Virginia Division of Natural Resources. We thank K. Oliveira for instructional guidance on otolith ageing techniques. Further, we thank E. Michael, K. Sheehan, and D. Smith for field assistance. The use of trade names or products does not constitute endorsement by the US Government.

\section{LITERATURE CITED}

Aieta AE, Oliveira K (2009) The distribution, prevalence, and intensity of the swim bladder parasite Anguillicola crassus in New England and eastern Canada. Dis Aquat Org 84:229-235

Barber I (2005) Parasites grow larger in faster growing fish hosts. Int J Parasitol 35:137-143

Barse AM, Secor DH (1999) An exotic nematode parasite of the American eel. Fisheries 24:6-10

Barse AM, McGuire SA, Vinores MA, Eierman LE, Weeder JA (2001) The swim bladder nematode Anguillicola crassus in American eels (Anguilla rostrata) from middle and upper regions of the Chesapeake Bay. J Parasitol 87: 1366-1370

Bush AO, Lafferty KD, Lottz JM, Shostak AW (1997) Parasitology meets ecology on its own terms: Margolis et al. revisited. J Parasitol 83:575-583

Casselman JM (2003) Dynamics of resources of the American eel, Anguilla rostrata: declining abundance in the 1990s. In: Aida K, Tsukamoto K, Yamauchi K (eds) Eel biology. Springer-Verlag, Tokyo, p 255-274

Castonguay M, Hodson PV, Couillard CM, Eckersley MJ, Dutil JD, Verreault G (1994a) Why is recruitment of the American eel, Anguilla rostrata, declining in the St. Lawrence River and Gulf? Can J Fish Aquat Sci 51: 479-488

Castonguay M, Hodson PV, Moriarty C, Drinkwater KF, Jessop BM (1994b) Is there a role in the ocean environment in American and European eel decline? Fish Oceanogr 3: 197-203

De Charleroy D, Grisez L, Thomas K, Belpaire C, Ollevier F (1990) The life cycle of Anguillicola crassus. Dis Aquat Org 8:77-84

Fazio G, Moné H, Da Silva C, Simon-Levert G, Allienne JF, Lecomte-Finiger R, Sasal P (2009) Changes in gene expression in European eels (Anguilla anguilla) induced by infection with swim bladder nematodes (Anguillicola crassus). J Parasitol 95:808-816

Fenske KH, Secor DH, Wilberg MJ (2010) Demographics and parasitism of American eels in the Chesapeake Bay, USA. Trans Am Fish Soc 139:1699-1710

Geer PJ (2003) Distribution, relative abundance, and habitat use of American eel Anguilla rostrata in the Virginia portion of the Chesapeake Bay. Am Fish Soc Symp 33: 101-115

Gollock MJ, Kennedy CR, Quabius ES, Brown JA (2004) The effect of parasitism of European eels with the nematode Anguillicola crassus on the impact of netting and aerial exposure. Aquaculture 233:45-54

Gollock MJ, Kennedy CR, Brown JA (2005a) European eels, Anguilla anguilla (L.), infected with Anguillicola crassus exhibit a more pronounced stress response to severe hypoxia than uninfected eels. J Fish Dis 28:429-436

Gollock MJ, Kennedy CR, Brown JA (2005b) Physiological responses to acute temperature increases in European eels Anguilla anguilla infected with Anguillicola crassus. Dis Aquat Org 64:223-228 
Hagy JD, Boynton WR, Keefe CW, Wood KV (2004) Hypoxia in Chesapeake Bay, 1950-2001: long-term change in relation to nutrient loading and river flow. Estuaries 27: 634-658

Han YS, Chang YT, Taraschewski H, Chang SL, Chen CC, Tzeng WN (2008) The swimbladder parasite Anguillicola crassus in native Japanese eels and exotic American eels in Taiwan. Zool Stud 47:667-675

Haro A, Richkus W, Whalen K, Hoar A and others (2000) Population decline of the American eel: Implications for research and management. Fisheries 25:7-16

Hildebrand H (2005) Size, age composition, and upstream migration of American eels at Millville Dam eel ladder, Shenandoah River, West Virginia. MSc thesis, West Virginia University, Morgantown, WV

Kangur A, Kangur P, Kangur K, Jarvalt A, Haldna M (2010) Anguillicoloides crassus infection of European eel, Anguilla anguilla (L.), in inland water of Estonia: history of introduction, prevalence, and intensity. J Appl Ichthyology 26(Suppl 2):74-80

Kemp WM, Sampou PA, Garber J, Tuttle J, Boynton WR (1992) Seasonal depletion of oxygen from bottom waters of Chesapeake Bay: roles of benthic and planktonic respiration and physical exchange processes. Mar Ecol Prog Ser 85:137-152

Kennedy CR (2007) The pathogenic helminth parasites of eels. J Fish Dis 30:319-334

Kennedy CR, Fitch DJ (1990) Colonization, larval survival and epidemiology of the nematode, Anguillicola crassus, in Britain. J Fish Biol 36:117-131

Kirk RS (2003) The impact of Anguillicola crassus on European eels. Fish Manag Ecol 10:385-394

Kirk RS, Kennedy CR, Lewis JW (2000) Survival and transmission of Anguillicola crassus Kuwahara, Niimi \& Itagaki, 1974 (Nematoda) in seawater eels. Parasitology 120:289-295

Lefebvre F, Contournet P, Crivelli AJ (2002) The health state of the eel swimbladder as a measure of parasite pressure by Anguillicola crassus. Parasitology 124:457-463

Lefebvre F, Contournet P, Crivelli AJ (2007) Interaction between the severity of the infection by the nematode Anguillicola crassus and the tolerance to hypoxia in the European eel Anguilla anguilla. Acta Parasitol 52: 171-175

> Machut LS, Limburg KE (2008) Anguillicola crassus infection in Anguilla rostrata from small tributaries of the Hudson River watershed, New York, USA. Dis Aquat Org 79:37-45

Molnár K (1993) Effect of decreased oxygen content on eels (Anguilla anguilla) infected by Anguillicola crassus (Nematoda: Dracunculoidea). Acta Vet Hung 41:349-360

Molnár K, Székely Cs, Baska F (1991) Mass mortality of eel in Lake Balaton due to Anguillicola crassus infection. Bull Eur Assoc Fish Pathol 11:211-212

Molnár K, Baska F, Csaba Gy, Glávits R, Székely Cs (1993) Pathological and histopathological studies of the swimbladder of eels Anguilla anguilla infected by Anguillicola crassus (Nematoda: Dracunculoidea). Dis Aquat Org 15:41-50

Molnár K, Székely Cs, Perényi M (1994) Dynamics of Anguillicola crassus (Nematoda: Dracunculoidea) infection in eels of Lake Balaton, Hungary. Folia Parasitol

Editorial responsibility: David Marcogliese,

Montreal, Quebec, Canada
(Praha) 41:193-202

Moravec F (2006) Dracunculoid and anguillicoloid nematodes parasitic in vertebrates. Academia, Prague

> Moravec F, Taraschewski H (1988) Revision of the genus Anguillicola Yamaguti, 1935 (Nematoda: Anguillicolidae) of the swimbladder of eels, including descriptions of two new species, A. novaezelandiae sp. n. and A. papernai sps. n. Folia Parasitol (Praha) 35:125-146

Morrison WE, Secor DH (2003) Demographic attributes of yellow-phase American eels (Anguilla rostrata) in the Hudson River estuary. Can J Fish Aquat Sci 60: 1487-1501

> Moser ML, Patrick WS, Crutchfield JU Jr (2001) Infection of American eels, Anguilla rostrata, by an introduced nematode parasite, Anguillicola crassus, in North Carolina. Copeia 2001:848-853

Nagasawa K, Kim YG, Hirose H (1994) Anguillicola crassus and A. globiceps (Nematoda: Dracunculoidea) parasitic in the swim bladder of eels (Anguilla japonica and $A$. anguilla) in East Asia: A review. Folia Parasitol (Praha) 41:127-137

Oliveira K (1996) Field validation of annular growth rings in the American eel, Anguilla rostrata, using tetracyclinemarked otoliths. Fish Bull 94:186-189

> Palstra AP, Heppener DFM, van Ginneken VJT, Székely C, van den Thillart GEEJM (2007) Swimming performance of silver eels is severely impaired by the swim-bladder parasite Anguillicola crassus. J Exp Mar Biol Ecol 352: 244-256

> Peters G, Hartman F (1986) Anguillicola, a parasitic nematode of the swim bladder spreading among eel populations in Europe. Dis Aquat Org 1:229-230

Richkus W, Whalen K (2000) Evidence for a decline in the abundance of the American eel Anguilla rostrata (LeSueur), in North America since the early 1980s. Dana 12:83-97

Rockwell LS, Jones KMM, Cone DK (2009) First record of Anguillicoloides crassus (Nematoda) in American eels (Anguilla rostrata) in Canadian estuaries, Cape Breton, Nova Scotia. J Parasitol 95:483-486

Sokolowski MS, Dove ADM (2006) Histopathological examination of wild American eels infected with Anguillicola crassus. J Aquat Anim Health 18:257-262

- Sprengel G, Lüchtenberg H (1991) Infection by endoparasites reduces maximum swimming speed of European smelt Osmerus eperlanus and European eel Anguilla anguilla. Dis Aquat Org 11:31-35

Tesch FW (2003) The eel. Blackwell Science, Oxford

van Banning P, Haenen OLM (1990) Effects of the swim bladder nematode Anguillicola crassus in wild and farmed eel, Anguilla anguilla. In: Perkins FO, Cheng TC (eds) Pathology in marine science. Proc 3rd Int Colloquium on Pathology in Marine Aquaculture. Academic Press, San Diego, CA, p 317-330

Würtz J, Taraschewski H (2000) Histopathological changes in the swimbladder wall of the European eel Anguilla anguilla due to infections with Anguillicola crassus. Dis Aquat Org 39:121-134

> Würtz J, Taraschewski H, Pelster B (1996) Changes in the gas composition of the swimbladder of the European eel (Anguilla anguilla) infected with Anguillicola crassus (Nematoda). Parasitology 112:233-238

Submitted: April 10, 2012; Accepted: August 27, 2012

Proofs received from author(s): October 31, 2012 